\title{
The network of mental health care from the family health strategy service
}

A rede de atenção à saúde mental a partir da Estratégia Saúde da Família

Red de atención en salud mental desde la estrategia salud de la familia

DOl: $\quad$ http://dx.doi.org/10.1590/19831447.2014.02.43052

\footnotetext{
a Nurse. PhD in Psychiatric Nursing, Graduate Program in Psychiatric Nursing, University of São Paulo at Ribeirão Preto College of Nursing. Associate Professor, School of Nursing, at Federal University of Rio Grande do Sul. Porto Alegre - RS - Brazil.

${ }^{b}$ Nurse. PhD in Psychiatric Nursing, Graduate Program in Psychiatric Nursing, University of São Paulo at Ribeirão Preto College of Nursing. Professor, Graduate Program in Nursing, Federal University of Rio Grande do Sul. Porto Alegre - RS - Brazil.

c Nurse. PhD in Nursing, Graduate Nursing Program, School of Nursing, University of São Paulo. Professor of the Graduate Program in Nursing at Federal University of Rio Grande do Sul. Porto Alegre - RS - Brazil.

d Nurse. Doctoral student, Graduate Nursing Program at Federal University of Rio Grande do Sul. Porto Alegre - RS - Brazil.

e Nurse. PhD in Nursing, Nursing Program, School of Nursing at Federal University of Rio Grande do Sul. Adjunct Professor, School of Nursing, Federal University of Rio Grande do Sul. Porto Alegre - RS - Brazil.

${ }^{f}$ Nurse. PhD in Nursing, University of São Paulo at Ribeirão Preto College of Nursing. Professor, Graduate Program in Nursing, Federal University of Rio Grande do Sul. Porto Alegre - RS - Brazil.
}

\section{ABSTRACT}

The Family Health Strategy Service (FHSS) is an important ally in the mental health system, contributing to the completeness and effectiveness of care. This study aimed to discuss the mental health care network as compared to the daily routine of an FHSS. It is an evaluative study with a qualitative methodological approach. It was developed in an FHSS in Porto Alegre-RS, Brazil. Data was collected between July and December of 2010 through interviews with 16 workers and ten relatives. We identified important resources in primary health care, such as partnerships with academia. However, the constitution of this care is still based on specialty, following the logic of patient referral. Our intention for this study was to contribute to the operationalization of the mental health care network, consolidating the partnership with the FHSS and developing activities in the territorial space, raising awareness, demystifying health care service in the area, and countering the perception that it is uniquely specialized.

Descriptors: Mental health. Health services. Primary health care.

\section{RESUMO}

A Estratégia de Saúde da Família (ESF) é um importante aliado na rede de atenção à saúde mental, contribuindo para a integralidade e efetividade do cuidado. Este estudo teve como objetivo discutir a rede de atenção em saúde mental a partir do cotidiano de uma ESF. É um estudo avaliativo, com abordagem metodológica qualitativa. Foi desenvolvido em uma ESF de Porto Alegre, RS, Brasil. Os dados foram coletados entre julho e dezembro de 2010, por meio de entrevistas com 16 trabalhadores e dez familiares. Identificamos importantes recursos de cuidado na atenção básica, como a parceria com a academia. No entanto, a constituição desse cuidado ainda está embasada no especialismo, com a lógica do encaminhamento. Pretendemos com esse estudo contribuir para a operacionalização da rede de cuidados em saúde mental, consolidando a parceria com a ESF e desenvolvendo ações no espaço territorial, sensibilizando e desmistificando a atenção na área como unicamente especializada.

Descritores: Saúde mental. Serviços de saúde. Atenção primária à saúde.

\section{RESUMEN}

La Estrategia Salud de la Familia es un importante componente de la red de salud mental, contribuyendo para la integralidad y efectividad del cuidado. Este estudio tuvo como objetivo discutir la red de atención en salud mental desde la Estrategia Salud de la Familia. Es un estudio evaluativo, con abordaje cualitativo. Fue desarrollado en una ESF de Porto Alegre-RS, Brasil. Los datos fueron recolectados entre julio y diciembre de 2010, con entrevistas aplicadas a 16 trabajadores y 10 familiares. Se identificó que hay recursos importantes de cuidado en salud mental en la atención primaria, como la relación con la academia. También, la concepción de cuidado está basada en la especialidad. Se pretende que se pueda contribuir en la operacionalización de la red de cuidados en salud mental, consolidando la articulación con la ESF y desarrollando acciones en el territorio, sensibilizando y desmitificando la salud mental, considerada únicamente especializada.

Descriptores: Salud mental. Servicios de salud. Atención primaria de salud. 


\section{口INTRODUCTION}

Psychiatric reform in Brazil is configured into a complex movement that aims to transform mental health practices. In this scenario, an articulate and dynamic network of substitute services emerges, considering care in the territory. The Family Health Strategy Service (FHSS), therefore, becomes an important ally in this network, contributing to the completeness and effectiveness of mental health care.

The FHSS constitutes a new health care model, and is responsible for generating new work processes emphasizing the importance of the subject and the collective in this construct. Operating by way of user-centered logic, the FHSS can transform the perspective of the worker in terms of the health/disease process, in addition to ensuring care focused on health promotion. ${ }^{(1)}$

One of the biggest challenges for FHSS is the integration of mental health and family health services. In this context, it translates into a starting, exit or arrival point for the user on their way to solving social and subjective problems. However, economic, social and cultural conditions, along with the connection to medical practices, reduces the community and inter-sectoral communication essential to the psychosocial field. Hence the need for this articulation ${ }^{(2-4)}$.

Therefore, it becomes important: to know the network of mental health care with a focus on the territory; strengthen the various inter-sectoral health resources and services that make up the plot of territorial connections; and contemplate the living space of the patients and their families. Making progress in this direction will enhance the view that mental health care should be performed outside the walls of health care facilities, since one of the premises of psychosocial care is precisely that the health care should be based on freedom, autonomy and self-governance.

Thus, we believe that knowing this organization will revitalize our relationships with the mentally ill by reducing stigma and prejudice. The mentally ill have long been relegated to the segregating institutions; however, mental illness and mentally ill patients should be seen beyond those walls, in their respective communities, in its territory, and finally, as the protagonists of their stories and life projects.

Therefore, in this study we considered the following question: What is the role of the mental health care network in the Family Health Strategy Service? To answer this question, we aimed to discuss the mental health care network as compared to the daily routine of the Family Health Strategy Service (FHSS).

\section{METHODOLOGY}

This study was part of the results for the MENTAL-FHSS (MENTAL-ESF) study ${ }^{(5)}$, which is evaluative and qualitative in nature. The central focus was to evaluate the daily routine of the service, its dynamics, the way the subjects interact and the meaning that is constructed in relationship to the practice itself. This was accomplished by way of a fourth-generation evaluation ${ }^{(6)}$.

When conducting the interviews we used a dialectical hermeneutic circle ${ }^{(6)}$. Initially, an open question was asked; the first interviewee was asked to discuss the mental health care in the FHSS. From this free expression, certain developments began to emerge, which, when analyzed, generated an initial analytical construct. This construct was inserted into other interviews, to allow the respondents to voice their opinions.

The method used in this study required that the collection and analysis of data be conducted in parallel processes, one driving the other, based on the constant comparative method ${ }^{(7-8)}$. According to this method, the whole interview is analyzed initially, providing an analytical unfolding, which is subsequently taken to interest groups for validation.

In the data analysis, the issues raised have been regrouped, allowing for the construction of markers to be used in both the internal and external evaluations. The following internal markers were defined: environment and characteristics of the working process. The external markers were: network management and coordination as well as the inter-sectorial approach. In this article we will discuss one of the themes of the marker network and management coordination: the mental health care network in the FHSS as a resource for mental health care.

Regarding methodological procedures, the study was carried out in an FHSS in Porto Alegre-RS, Brazil. Data was collected between July and December of 2010, through interviews with interest groups: 16 employees, ten patients and ten family members. In this study, we also used data from interviews with 16 professionals from the FHSS, in addition to ten family members.

The following is the criterion for being considered a "professional": having worked for at least six months. Professionals who were on leave or on vacation were excluded, and those who were willing to participate voluntarily in the study were selected. As far as families were concerned, those with good interaction in the FHSS were included, meaning those that the team considered to have actively participated in the patient's mental health care. Those who were unwilling to participate, or allow the dissemination of results, were excluded from the data collection in order to avoid any ethical issues.

The study was approved by the Research Ethics Committee of the city of Porto Alegre, under the official opinion 001.056577.08.7/2008. All subjects signed a Written Consent Form. To ensure anonymity, the subjects were identified by the letters S (staff) and F (family), followed by the number representing the order of the interview. 


\section{RESULTS AND DISCUSSION}

As a result of the psychiatric reform movement, mental health care has experienced a complex process of self-assertion by a do/know which far exceeds the hospital-centered, biomedical and medicalized models ${ }^{(9)}$. In this sense, the mental health network should consist of several spheres that embody a process of care that includes freedom and teams that can count on support from territorial resources, with the purpose of enhancing the effects of care and psychosocial rehabilitation ${ }^{(10)}$.

As discussed previously, the Family Health Strategy Service (FHSS) is constituted as a resource with the potential for innovation, with mental health being one of its pillars. However, in our case, the Picturesque FHSS staff admits that the network currently available is still focused on the traditional curative and biomedical psychiatric model:

The network is structured for a patient profile, user profile, of a client of the old mental health approach, which was a mental health oriented towards hospitalization and/or a serious disorder [...] hospitalization, restraint and a lot of medication and almost no use of a territorial base. (E13)

Workers indicate that the network does not exist by itself, but rather establishes itself and takes it life from actions by the workers, based on the dialogue and knowledge of the various services included. The articulation and activation of the network occur according to perspectives on the health problem, which can be seen from elements of traditional psychiatry, which focuses on the complaint/symptom, which can be activated by the "look" of patients and their suffering:

The coordination and activation of the mental health care network depends on whether the network provides a professional perspective - a perspective beyond the complaint/symptom explained by the user. (E13)

Another issue raised by the professionals is the lack of support for care of the most serious and urgent cases, by way of a Brazilian public mental health center (CAPS) in the territory covered by the service. This refers to the importance of hospitalization not being the only resource for mental health care. An alternative would be the implementation of a CAPS in Lomba do Pinheiro/Parthenon, which would improve mental health services and the relationship among the various services.

A CAPS for us here in Parthenon does not exist [...] A CAPS would be very good for the people ... but we do not have one. (E19)
And furthermore, you have idea of the lack of resources in general, having a CAPS, a specialized service for this problem, there are few resources for this. (E9)

In this quote, CAPS is a reference to the demand for mental health at the Picturesque FHSS, in addition to the CAPS at the Hospital de Clínicas de Porto Alegre (HCPA). However, integration between the two services is weak, because access is limited and demand is high:

The CAPS of the Hospital de Clínicas, we hardly have access to this, which is supposed to be our reference. (E17)

The aforementioned CAPS does not provide any form of welcoming, only offering screenings based on availability. "Welcoming" here is understood to mean a strategy of changing the treatment model to one based on quality of life, the promotion of health and independence, and comprehensiveness of care for the population. It is a strategy that proposes the integration of demand and the organization of activities aimed at the health of the individual/family, intervenes in the dynamics of the working process, and establishes a closer relationship between users and professional services ${ }^{(11)}$.

It is noteworthy that none of the CAPS in the city of Porto Alegre has an open-door policy, which would offer the possibility of access without using intermediate mechanisms such as screening, scheduling, and appointments, among others. The low number of CAPS in the city is not conducive to the effective mapping of centers that do exist, so they end up constituting a reference center for a population that exceeds capacity. This makes it difficult to establish a dialog with the specifics of the geographical and cultural territory of users.

In large capitals such as the city studied, barriers to entry increase due to the distances between the places where people live and the places where they can obtain treatment, weakening the connection and integration among workers at different points in health care access as well as with the territory.

The dynamics of use and occupation of the territory, which suffers from the influence of economic, environmental, social and cultural factors, has significant implications for the health of individuals and the availability of health care. In this case, the peculiarities of metropolitan areas, such as the elevated mobility of the population and the availability in the most central area of the metropolis, and of numerous and varied health services at various levels of complexity, significantly impact access to and utilization of health services. This situation sometimes goes against the guidelines and principles of organization of the Unified Health System (the national public health system, referred to by the acronym SUS) ${ }^{(12)}$. 
The absence of a CAPS in the territory studied is the reality that is mirrored by many other realities in this city, showing the absence of a mental health policy committed to the guidelines and assumptions of Brazilian psychiatric reform. This reinforces the continuity/permanence of the greater centrality of psychiatric hospital in mental health services. The FHSS workers, when faced with difficulties in accessing replacement services, continue forwarding the mental health cases in the territory to the psychiatric hospital:

\section{It is only in the Spiritist (hospital). (E16)}

The family members also identify this limitation: they realize they are welcomed by the staff and that, within limits, they can receive a follow-up to their demands in the field of mental health care. These limitations are mainly related to the fact that "there are a lot of people to attend to," i.e., the service is timely in solving a given problem, but does not have time for therapeutic dialog. Despite identifying the possibility that monitoring could occur in the FHSS, family members emphasize that when follow-up involving specialized service is required, the team's main option is to send the patient to the psychiatric hospital:

There is no direct way to talk to a psychologist. The doctor talks to me sometimes. There are a lot of people for her to attend to [...] it was just depression, she talked with me. When it got to the point that I could not leave the house, then she referred me to Sao Pedro. (F4)

The lack of a mental health care network was one of the aspects that were relevant during the evaluation process in this study. However, this need was perceived in situations that demanded round-the-clock care for users with so-called serious disorders. Workers realized that there are other needs in regards to mental health care, which cause intense suffering and inability to live life regularly, but do not have their origin in a psychiatric disorder, as can be seen in the following testimonies:

There is the issue of psychological suffering, which has become somewhat dominant in mental health care and, ultimately, what we see a lot of is anxiety disorders, depressive issues, and things that are not as severe, until the point where the individual needs to be hospitalized, institutionalized. Patients who, in most cases, are sent to the outpatient clinic and this is something that I think society itself can nowadays cause a lot of, these types of anxieties and depression. Structurally, this leads to a situation that we have a lot of demand for. (E13)
We had a situation where a mother arrived, she came here crying, chatted with me and spent some time talking. And then, because she has two daughters and both of them began to use drugs [...] and on top of that she discovered that the one girl likes girls [...]. And then, so, she came here, talked, vented, cried, and talked a lot. I said what I could, I spoke until I could no longer. But in that case, what did I need at that moment? I needed to have somewhere to refer her to, principally, someone to refer the mother to for therapy. (E15)

Evidence showed the need for the creation of new operational strategies within the FHSS, based on actual mental health demands, so that professionals can accommodate and take responsibility for these people, who may be referred within their territory without having to opt for care in specific mental health services.

Meeting the demands for mental health care is qualified and enhanced by way of the matrix of the support team and the partnership with the School of Nursing of the Universidade Federal do Rio Grande do Sul (UFRGS), which develops practical activities in this FHSS. Moreover, to the extent that the staff feels supported, it accepts responsibility for this type of care in the unit itself, breaking away from the automatic and naturalized cycle of referral to specialized services. However, strategies that provide users with social inclusion, therapeutic spaces and continuity of care all need to be amplified:

We have a pretty good support team and what comes from the outside that aggregates value is the matricial guidance [...] the Professor from UFRGS, which gives us good support [...] Could we have something better, more programs for them to be involved with, for patients not to take so much medicine, which I think the question is more drug control, thus more control of their own disease with medication, I think if I had something more to able to do, therapies, groups, government programs would be more interesting, we have very few. There isn't much access, besides having only a few, access is not very well publicized. (E3)

The presence of traditional psychiatric institutions in the district, especially the psychiatric hospital in Sao Pedro, has created a very strong culture in the territory toward the asylum model, to such an extent that hospitalization of patients was the path used by the community for several decades, which creates complications and barriers when proposing to change the model. Paradoxically, this presence also enables access to organized structures and the establishment of partnerships with the respective employees, which has enabled the Picturesque FHSS to make referrals for various situations: 
Here in our district, by having the legal conditions, personal conditions, the necessary network and management for the logistical support for the outpatient clinic, to have Sao Pedro, to have a mental health team, to have Tobias Barreto, after all, with these resources we're managing to have a nice result. (E13)

The reflections of this asylum culture are also perceived in the group of family members. However, some family members are unaware and others are reluctant to use this new modality of care, because up to now they were only accustomed to services within the psychiatric hospital, based on the asylum model:

Look, I was thinking this was bad, because I was used to treating him at Sao Pedro, but then I saw that it was necessary, he was actually released and some people need it more than him. So I forwarded him back to the outpatient clinic. There are people with more problems that need to be treated. It was left open. If it gets worse, or something like that, then you can take a look at San Pedro. (F2)

This resistance is reinforced by the fact that many specialized services in the city of Porto Alegre do not comply with the proposed regulations, developing mechanisms for access that lack transparency, not allowing for the FHSS to be established as a gateway for these patients. Family members, when they are able to access FHSS services, know that losing their connection with the more specialized services means that when they need them, this door will not be as open as before.

In regards to referrals, we realize that in most cases they are faster and more effective when they are coordinated with the psychiatric hospital San Pedro:

I think so, because they quickly sped up the consultation for the patient. (F2)

I think it is fast. They were quick. It doesn't get stuck in that bureaucracy, that type of bottleneck ah ... I'll tell send to you, I will send and do not send anything. I also found this part of making referrals to be very fast. (F10)

However, when the FHSS needs to make referrals to services that make up the health care network in Porto Alegre, it often becomes a "sacred path" for the patients and their family. This is due to the fact that there are great distances between the different health care services, and also because often those services cannot handle the demand, leaving patients and their families at the mercy of the availability of the services:
Far, far away ... and at Pinheiro they did not want to attend, at Bom Jesus neither. Then I had to go Cruzeiro. And sometimes there are other clinics that you do not want. Once they said that we do not belong to the territory. I said: Ah ... but I came here because my outpatient clinic told me to come here. (F4)

You go looking, I looked to be attended at UFRGS, it didn't work. I've searched all over the place. Being that I help the LBV - Legião da Boa Vontade (Legion of Good Will), I also called the Legion of Good Will and they also do not have any availability. (F6)

Family members also questioned the legitimacy of the referrals to other services made by the FHSS staff because there is often a doctor's note to guide the health care, and when the patient presents the document, it is not taken into account. This prevents the referral and counter-referral system from actually becoming effective:

There should be no need for all this sacred path, it is too large. Because just as the doctor is competent, who is treating that person, I also think that his prescription must be valid in order to arrive there at the triage and treat the patient. The doctor has the right to authorize ... it sure is something, disqualifying the doctor himself. (F9)

Difficulties in communication do not happen unilaterally. When the patient is released from a specialized health care service, the counter-referral should be operationalized, it is essential for continuity of care. The FHSS team identifies this difficulty, because when the patient returns, there is no document describing where patient is coming from and what services were received:

Sometimes we get the doctor's notes from the Spiritist Hospital and then we forward them to the units, well then we look into it, but not always, it is not always, sometimes it is three months later. (E17)

However, some workers suggested that FHSS referrals to specialized services have evolved and communication between the health services has improved, mainly through regular meetings to discuss cases:

The issue of referrals is evolving. I think in general partnerships with both the Santa Marta outpatient clinic, with SIABS, with Sao Pedro we always have meetings with them, twice a month: we have a meeting with the clinic to discuss the cases that are in need of basic attention from each unit. (E17)

I think we're managing to make the referrals correctly. (E16) 
It's not just redirection of the health care resources in the community that is crucial to achieving the deinstitutionalization of mental patients. The isolation and exclusion of the mentally ill from life in society are supported by a certain way of dealing with differences, by phenomena which, within a given public policy, are considered foolish. There is a need to dismantle the perceptions/knowledge that identify experiences of pathology as symptoms of mental illness, with concomitant creation of new modes of sociability and production of social value ${ }^{(13)}$.

We can say that psychiatric reform relates to a change in public mental health care policies, in order to prioritize community care for psychiatric patients at the expense of the asylum model, leading to treatment of mental illness in the psychiatric institution for the social rehabilitation of users in the community ${ }^{(13)}$. This challenge is understood as being pertinent in the context of mental health, in order to reposition a subject long forgotten in conventional spaces of health care services and promote recognition of the need for composing networks that are attentive to the individuals' qualities, needs, realities and contexts.

\section{qINAL CONSIDERATIONS}

The coordination of mental health care through a dynamic and connected network is a challenge in the new landscape of public health care policies in Brazil. Ensuring access, care, prevention, resolution and rehabilitation for the users of health care services is becoming intriguing for professionals.

Our intention for this study is to contribute to the operationalization of the mental health care network, consolidating the partnership with the FHSS and developing activities in the territorial space, raising awareness, demystifying the healthcare service in the area, and countering the perception that it is uniquely specialized.

Regarding the implications of the results of this evaluation of mental health care activities in the FHSS, the biggest challenges for psychiatric reform are deficiencies in the mental health care network and distorted conceptions of specialization as a desirable solution to mental health issues. The evaluation of the interest groups demonstrates the need to invest in strategies that can overcome this logic.

In this sense, we visualize the scenario studied as a priority, a necessary and current space for investigations that introduce changes and creativity in mental health care within the territory.

\section{DEFERENCES}

1. Fortuna CM, Matumoto S, Pereira MIB, Mishima SM, Kawata LS, Camargo-Borges $C$. Nurses and the collective care practices within the family health strategy. Revista Latino-Am Enfermagem. 2011;19(3):581-8.

2. Buchele F, Laurindo DLP, Borges VF, Coelho EBS. A interface da saúde mental na Atenção Básica. Cogitare Enferm. 2006;11(3):226-33.

3. Pinto AGA, Jorge MSB, Vasconcelos MGF, Sampaio JJC, Lima GP, Bastos VC, et al. Apoio matricial como dispositivo do cuidado em saúde mental na atenção primária: olhares múltiplos e dispositivos para resolubilidade. 2012;17(3):653-60.

4. Bosi MLM, Carvalho LB, Ximenes VM, Melo AKS, Godoy MGC. Inovação em saúde mental sob a ótica de usuários de um movimento comunitário no nordeste do Brasil. Cienc Saúde Colet. 2012;17(3):643-51.

5. Olschowsky A, coordenadora. Avaliação da saúde mental na Estratégia Saúde da Família (MENTALESF): relatório final. Porto Alegre: Universidade Federal do Rio Grande do Sul; 2011.

6. Guba EG, Lincoln YS. Fourth generation evaluation. Newbury Park: Sage Publications; 1989.

7. Guba EG, Lincoln YS. Naturalistic inquiry. Newbury Park: Sage Publications; 1985.

8. Kantorski LP, Wetzel C, Schwartz E, Jardim VMR, Heck RM, Bielemann VLM, et al. Uma proposta metodológica quantitativa e qualitativa de serviços de saúde mental: contribuições metodológicas. Saúde em Debate. 2009;33(82):273-82.

9. Lucchese R, Oliveira AGB, Conciani ME, Marcon SR. Saúde mental no Programa Saúde da Família: caminhos e impasses de uma trajetória necessária. Cad Saúde Pública. 2009; 25(9):2033-42.

10. Ministerio da Saúde (BR), Secretaria de Atenção à Saúde. Saúde mental e atenção básica: 0 vínculo e 0 diálogo necessários - inclusão das açōes de saúde mental na atenção básica. Braślia (DF); 2003.

11. Coimbra VCC. 0 acolhimento em centro de atenção psicossocial. Rev Enferm UERJ. 2005;13(1):57-62.

12. Machado CV, Lima LD. Os desafios da atenção a saúde em regiões metropolitanas. In: Giovanella. L. et al., organizadores. Políticas e sistema de saúde no Brasil. Rio de Janeiro: Fiocruz; 2008. p.945-77.

13. Silva MBB. Atenção psicossocial e gestão de populações: sobre os discursos e as práticas em torno da responsabilidade no campo da saúde mental. Physis 2005;15(1):127-50

\section{Author's address:}

Leandro Barbosa de Pinho

Rua São Manoel, 963, Rio Branco

90620-110, Porto Alegre, RS

E-mail: lbpinho@ufrgs.br
Received: 10.10.2013

Approved: 21.03.2014 